UDC 615.213: 615.322

DOI: 10.15587/2519-4852.2018.129599

\title{
METHODOLOGICAL APPROACHES TO THE SEARCH OF NEW HERBAL ANTICONVULSANTS
}

\author{
(C) Y. Prokopenko, V. Georgiyants
}

\begin{abstract}
Мета. Розробка найбільш підхожого алгоритму пошуку та вибору лікарських рослин, щу мають протисудомну активність, а також оцінити рівень протисудомної активності різних груп біологічно активних речовин рослинного походження за допомогою програми PASS.

Методи. Для розробки логічного алгоритму пошуку найбільш підхожих рослин, щзо надають протисудомну дію, використовували аналіз літературних даних та програмне забезпечення PASS.

Результати. При розробці алгоритму изілеспрямованого пошуку рослин для лікування епілепсї найбільш раціональним рішенням було розподілити рослини відповідно до їх хімічного складу та механізмами дії. Було виявлено, шьо певні групи біологічно активних речовин (алкалоїди, флавоноїди, фенольні кислоти) та деякі представники родин Betulaceae, Papaveraceae, Solanaceae, Fumariaceae, Lamiaceae, Polemoniaceae, Viscaceaе та Oleaceае мають протисудомну активність. Результати PASS прогнозу свідчать про те, щзо для речовин, щуо вивчались, притаманна протиепілептична дія, хоча вона не є визначною. Аналіз результатів вивчення алкалоїдів протопіп та сангвінарин викликав особливу увагу завдяки високим показникам активності-0,813 та 0,820\%, відповідно.

Висновки. Було обтрунтовано алгоритм вибору найбільш перспективних рослин для подальшого детальнішого вивчення стосовно можливостей їх використання для лікування епілепсї. Для різних груп біологічно активних речовин був здійснений аналіз фармакологічної активності за допомогою програми PASS. Як і очікувалося, відповідно до результатів PASS аналізу, для більшості речовин, щуо вивчались, протиепілептична активність присутня, проте не є визначальною. Існує певна ймовірність прояву протиепілептичної активності аналізованими сполуками: індекси активності аналізованих речовин знаходяться в діапазоні від 0,430 \% до 0,754\%. Деякі біологічно активні речовини характеризувались наявністю нейропротекторної активності; найвищі показники спостерігались для амінокислот гістидин (0,680\%) та аланін $(0,718 \%)$. Амінокислоти аспарагін та серин характеризувались здатністю активувати розумову діяльність (0,489\% та 0,554\%, відповідно)
\end{abstract}

Ключові слова: протиепілептична активність, рослини, субстаниії рослинного походження, алгоритм, програма PASS, індекс активності

\section{Introduction}

New herbal remedies are still under active research, especially when it comes to development of drugs for treatment of chronic diseases, i.e. epilepsy. Nowadays, herbs are the most common approach to alternative therapy for control epileptic seizures or complications caused by synthetic antiepileptic drugs. A number of herbal products have been used in traditional medicine worldwide, and traditional herbs are very useful and irreplaceable in epilepsy treatment effort. Herbal remedies may provide high possibilities both for scientists and for pharmaceutical companies in implementation of new antiepileptic drugs.

2. Formulation of the problem in a general way, the relevance of the theme and its connection with important scientific and practical issues

There are different overwhelming reviews concerning herbs or herbal substances applied for treatment of epilepsy $[1,2]$. But the existing volumes of information are difficult to organize and use for the further research. Development of universal search algorithms will help the scientists to introduce the effects of herbal medicine on epilepsy. It's worth mentioning that the effects of herbal medicine may be difficult to predict, especially due to the fact that active ingredients are changeable and often unknown. The traditional way to study pharmacological activity of new herbal medicinal substances is in their isolation and then in different tests using different pharmacological models [3]. Complexity, high cost and duration of this process requires development of new theoretical foundations for drug search. Recently, there are different possibilities to increase efficiency and rationality of the studies in area of the search of new herbal substances by using modern software. Therefore, relatively young technology of computer design of medical substances is increasingly used by scientists and pharmaceutical companies worldwide [4].

\section{Analysis of recent studies and publications in} which a solution of the problem and which draws on the author

Herbal medicine for epilepsy treatment is a centuries-old practiced medical form in different cultures. Literature sources have shown that a lot of medicinal herbs with anticonvulsant activity are characterized by the content of powerful pharmacologically active compounds [1-3]. It has already been mentioned that the role of individual compounds of herbal origin is poorly understood, and the modern software programs, i.e. PASS, will help scientists to understand this connection.

PASS analysis is based on «structure - activity» correlation studies for a training set of substances containing more than 45000 various biologically active ones. Besides, the training set is constantly is updated with new information concerning biologically active sub- 
stances, selected from both publications in the scientific and technical literature, and from numerous databases. The average prediction accuracy is more than $85 \%$ [5].

\section{Allocation of unsolved parts of the general problem, which is dedicated to the article}

The lack of a clear algorithm for finding the most suitable herbs for further studies significantly complicates research work in this direction. Besides, PASS prognosis can be useful at the experiment planning stage and will help to select the most promising herbs and herbal substances with potential anticonvulsant activity. Unfortunately, there are no literature data about such type of PASS analysis.

\section{Formulation of goals (tasks) of Article}

The aims of the present research were to develop the most appropriate algorithm for the search and selection of herbs showing anticonvulsant properties, as well as to interpret the level of anticonvulsant activity of different groups of herbal substances using PASS tool.

\section{Statement of the basic material of the study (methods and objects) with the justification of the results}

It should be mentioned that during the selection of the most promising herbs it is necessary to rely on data concerning their chemical composition, mechanism of action, and the possibility of their use to correct the nervous system disorders. Thus, the most rational decision in case of development of the algorithms for the targeted search of herbs for epilepsy treatment is to divide herbal objects according to their chemical composition and mechanism of action.

Based on the informational data of experimental studies in specialized journals, it was found that certain groups of biologically active compounds have anticonvulsant activity. Besides, the obtained data made it possible to divide the mentioned compounds depending on the direction of epilepsy treatment: pathogenetic, symptomatic and cognitive disorders correction. At the same time, traditional medicine experience shows the presence of anticonvulsant properties in some members of the Betulaceae, Papaveraceae, Solanaceae, Fumariaceae, Lamiaceae, Polemoniaceae, Viscaceae, and Oleaceae families. Therefore, the summary analysis of the given information has allowed simplifying decision making in the algorithm development.

The mechanism of development of seizures is mainly associated with a violation of the exchange and functions of neurotransmitter systems of synaptic transmission. Knowledge of neurotransmitter mechanisms of antiepileptic drugs is important both from the theoretical and the practical points of view. It is known that glutamatergic and GABAergic systems play important roles in epileptic seizure [6].

Currently, there is no universally accepted definition for pathogenesis of epilepsy. Numerous studies are devoted to the pathogenesis of seizures. It is known that the group of compounds playing a significant role in the pathogenetic therapy of epilepsy includes alkaloids berberine, solasodine, protopin [7-9], as well as flavo- noids and phenolic acids (luteolin, quercetin, fumaric acid) [10].

Literature sources have shown that alkaloids have anticonvulsant activity probably due to their interaction with $\mathrm{GABA}_{\mathrm{A}}$ receptors. Both isoquinoline and tropane alkaloids can act as weak $\mathrm{GABA}_{\mathrm{A}}$ receptor agonists and demonstrate their anticonvulsant activity by modulating neurotransmitter systems [11]. Besides, it was found that protopine can also block serotonin and noradrenaline transporters and, therefore, act as antidepressant [12].

Flavonoids can exert antiseizure activity mainly by modulating $\mathrm{GABA}_{\mathrm{A}}$ receptors due to their structural similarity to benzodiazepines [10]. Some scientists believe that phenolic nature of these compounds contributes to their ability to ruin cellular oxidative processes in the central nervous system. It was shown that, for example, flavones can act as selective benzodiazepine receptor ligands [13]. Therefore, flavonoids are promising substances of herbal origin for development of new remedies for treatment of $\mathrm{GABA}_{\mathrm{A}}$ receptor-mediated disorders.

It is known that symptomatic therapy of epilepsy is to control acute symptomatic seizures, which can be achieved through a variety of substances. For example, literature data have shown that atropine due to its central activity reduce duration and overall intensity of seizures [14]. Besides, similar neuroactive properties have some flavonoids. The studies have shown that rutin and isorhamnetin can reduce seizure severity, as well as improve memory processes after traumatic brain injury and brain ischemia $[1,10]$. Despite rutin has rather weak and shortterm anticonvulsant potential, this compound seems to be promising for epilepsy treatment due to the absence of adverse effects. Ursolic acid also shows anticonvulsant activity expressed in a decrease of the number of seizures and lethality in mice [10]. Some scientists explain pharmacological activity of the mentioned substance by facilitation of GABA transmission and GABA receptor stimulation $[6,11]$.

The other problem for patients suffering from epilepsy is cognitive disorders, which may occur to be more problematic and severe than seizures. The most common co-morbidities on the background of epilepsy are cognitive dysfunction (memory, attention), mental health conditions (depression, anxiety), and somatic co-morbidities (sleep disorders, migraines). Rational use of effective drugs, including herbs, can help to reduce their impact on the patient's quality of life. The newest studies have shown that rosmarinic and ferulic acids are the most promising substances of herbal origin, which could reduce the appearance of these disorders and improve their prognosis [15]. Thus, the scientists have found that rosmarinic acid increased the immobility time in the forced swim test, has antidepressant-like effect, anxiolytic-like activity, and moreover, this compound did not cause adverse effects on spontaneous (open-field crossings) or forced (rotarod) motor performance [10, 15]. Besides, international studies have shown that there is a significant positive correlation between the doses of rosmarinic acid and the latency to PTZ-induced and pilocarpineinduced seizures in mice [15]. The same experiment resulted that the animals treated with rosmarinic acid have shown only mild or moderate behavioural signs. 
Therefore, based on the above information, we selected the most promising herbs for the further detailed phytochemical and pharmacological studies. The developed algorithm of the search of herbal objects applied for treatment of epilepsy is shown in Fig. 1. As it can be seen, different groups of biologically active compounds and different herbs can be used as anticonvulsant agents.

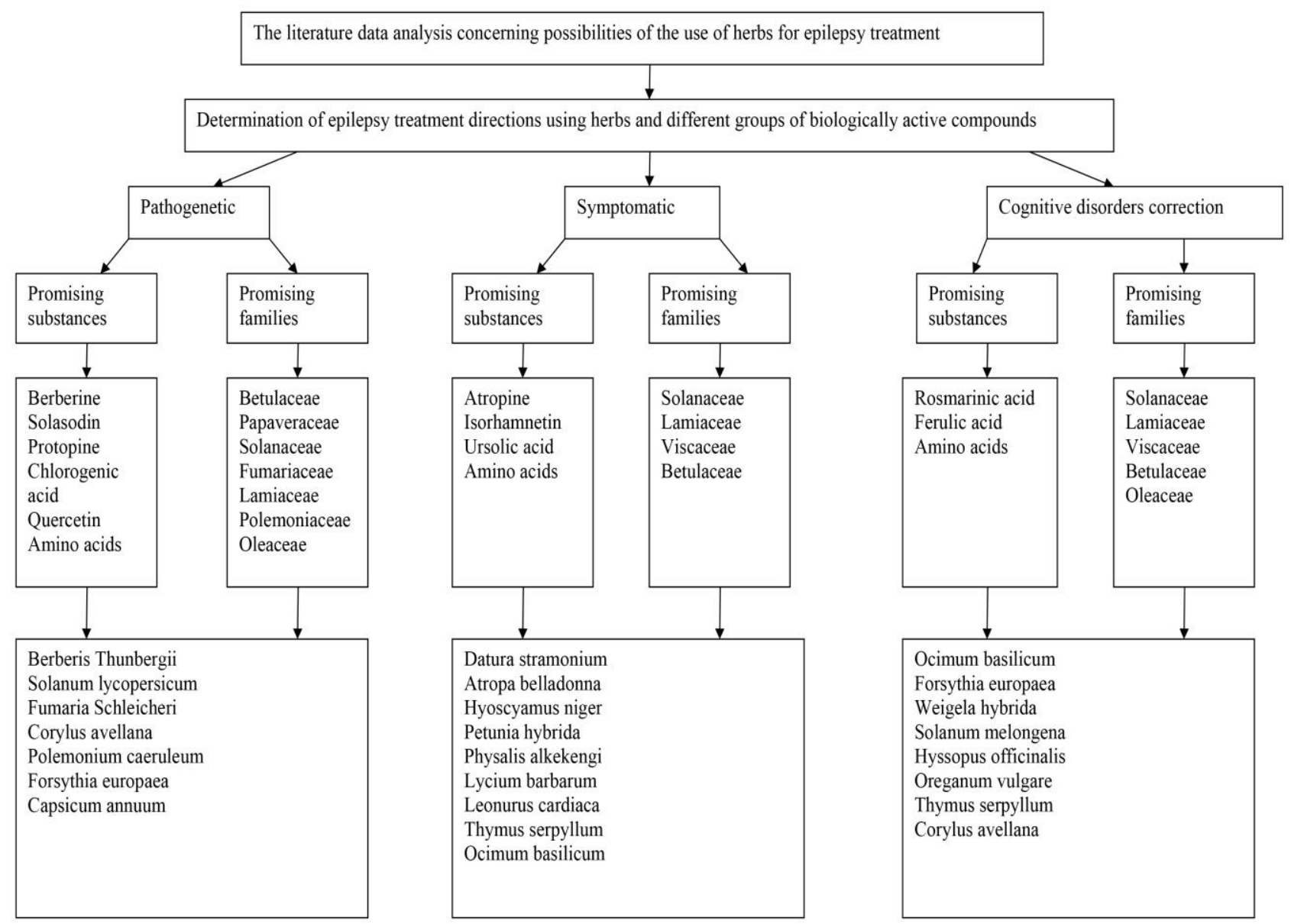

Fig. 1. Algorithm of the search of herbal objects applied for treatment of epilepsy

For preliminary analysis of the probable anticonvulsant activity of the selected substances and for the further determination of the possibilities of the use of the mentioned herbs, computer prediction of pharmacological activity was carried out using PASS software. Thus, among the mentioned compounds, the most promising herbal substances having anticonvulsant, antiepileptic, GABA inhibitor activity, and neuroprotective activity were found by PASS tool. Besides, this software can be also useful for prediction of probable mechanisms of action of the given substances.

As a rule, chemical structure of natural compounds often stipulates wide spectrum of biological activity of herbs. Nevertheless, according to the PASS analysis, antiepileptic activity is inherent, but not significant for most of the studied compounds.

Concerning pathogenetic direction of epilepsy treatment, a significant number of the analyzed compounds have the likelihood of manifestation of anticon- vulsant activity by interaction with GABA receptors. The indexes of activity of the analyzed substances are in range from 0.358 to $0.813 \%$ (Fig. 2).

Among the present above compounds, particular expectations caused the analysis of the results of alkaloids protopine and sanguinarine due to their high indexes of activity -0.813 and $0.820 \%$, respectively. It also should be mentioned, that some compounds, e.g. chlorogenic acid and quercetin didn't show any other type of prediction of anticonvulsant activity except interaction with GABA receptors $(0.460$ and $0.395 \%$, respectively).

Among the other types of manifestation of antiseizure activity for the studies herbal substances, anticonvulsant and antiepileptic activity were found by PASS tool. Thus, only sanguinarine and histidine have shown probable presence of anticonvulsant activity $(0.473 \%$ and $0.318 \%$, respectively). Indexes of antiepileptic activity are displayed in Fig. 3. 


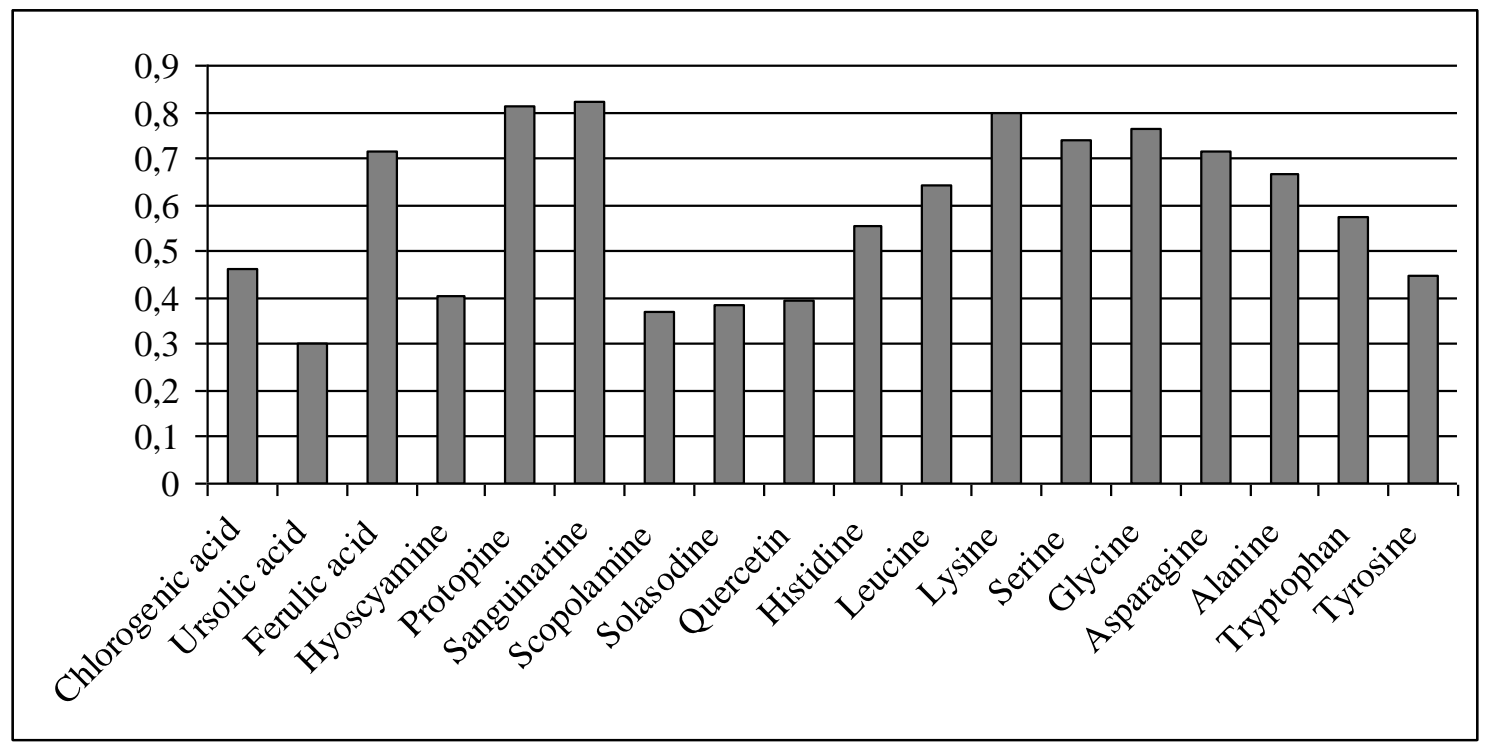

Fig. 2. Prediction of interaction with GABA receptors probability for herbal substances

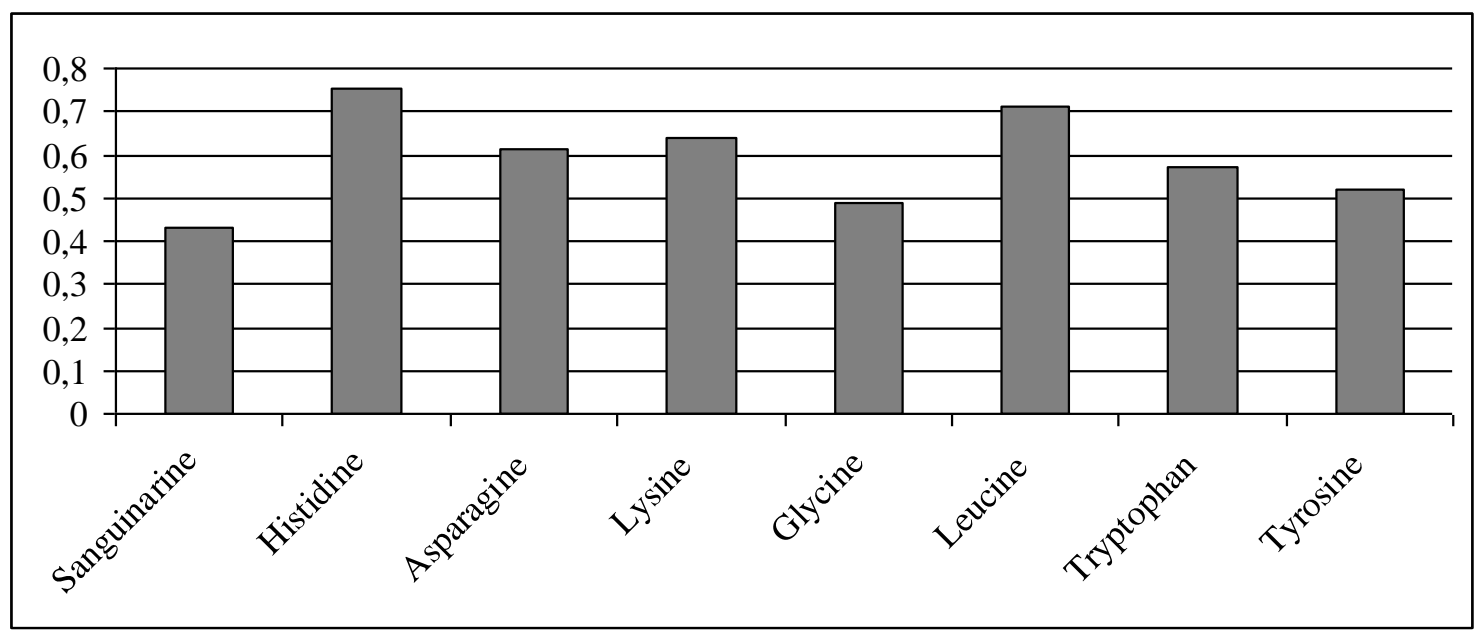

Fig. 3. Indexes of antiepileptic activity for the studied herbal substances

Moreover, it was found that several biologically active compounds may have neuroprotector activity, e.g.: ferulic acid $(0.510 \%)$, protopine $(0.426 \%)$, sanguinarine $(0.649 \%)$, histidine $(0.680 \%)$, asparagine $(0.671 \%)$, serine $(0.527 \%)$, alanine $(0.718 \%)$, tryptophan $(0.650 \%)$, and tyrosine $(0.668 \%)$. Concerning the importance of cognitive disorders correction as a part of epilepsy therapy, protopine has shown probable presence of antidepressant activity $(0.321 \%)$, which agrees with the experimental studies data [12]. Amino acids asparagine and serine have shown probable presence of cognition activator activity $(0.489 \%$ and $0.554 \%$, respectively).

\section{Findings from the research and prospects of further development of this area}

The choice of the most promising herbs for the further detailed phytochemical and pharmacological studies concerning possibilities of their use for treatment of epilepsy was substantiated.

The algorithm of the selection of the most promicing herbs and herbal substances according to the literature data was developed.
To confirm or refute the given data, PASS prediction analysis for different groups of herbal substances was carried out. As expected, according to the PASS prediction results, antiepileptic activity is inherent, but not significant for most of the studied compounds.

Particular expectations caused the analysis of the results of alkaloids protopine and sanguinarine due to their high indexes of activity by interaction with GABA receptors -0.813 and $0.820 \%$, respectively. Sanguinarine and histidine have shown probable presence of anticonvulsant activity $(0.473 \%$ and $0.318 \%$, respectively). Besides, the analyzed compounds have the likelihood of manifestation of antiepileptic activity: the indexes of activity of the analyzed substances are in range from 0.430 to $0.754 \%$.

Several biologically active compounds may have neuroprotector activity; the highest indexes were obtained for histidine $(0.680 \%)$ and alanine $(0.718 \%)$. Amino acids asparagine and serine have shown probable presence of cognition activator activity $(0.489 \%$ and $0.554 \%$, respectively). 


\section{References}

1. Plants and Plant Products with Potential Anticonvulsant Activity - A Review / Kumar S. et. al. // Pharmacognosy Communications. 2012. Vol. 2, Issue 1. P. 3-99. doi: 10.5530/pc.2012.suppl1.2

2. Nsour W. M., Lau C. B.-S., Wong I. C. K. Review on phytotherapy in epilepsy // Seizure. 2000. Vol. 9, Issue 2. P. 96-107. doi: 10.1053/seiz.1999.0378

3. Influence of dry herbal extracts on pentylenetetrazole-induced seizures in mice: screening results and relationship "chemical composition - pharmacological effect" / Tsyvunin V. et. al. // ScienceRise: Pharmaceutical Science. 2016. Issue 1 (1). P. 18-28. doi: 10.15587/2519-4852.2016.71518

4. Krovat E., Steindl T., Langer T. Recent Advances in Docking and Scoring // Current Computer Aided-Drug Design. 2005. Vol. 1, Issue 1. P. 93-102. doi: 10.2174/1573409052952314

5. Discriminating between Drugs and Nondrugs by Prediction of Activity Spectra for Substances (PASS) / Anzali S. et al. // Journal of Medicinal Chemistry. 2001. Vol. 44, Issue 15. P. 2432-2437. doi: 10.1021/jm0010670

6. Mathews G. C. The Dual Roles of GABA in Seizures and Epilepsy Generate More Excitement. Epilepsy Currents. 2007. Vol. 7, Issue 1. P. 28-30. doi: 10.1111/j.1535-7511.2007.00159.x

7. In Vivo Anticonvulsant Activity of Extracts and Protopine from the Fumaria schleicheri Herb / Prokopenko Y. et. al. // Scientia Pharmaceutica. 2015. Vol. 84, Issue 3. P. 547-554. doi: 10.3390/scipharm84030547

8. Mojaradl T. B., Roghani M. The anticonvulsant and antioxidant effects of berberine in kainate-induced temporal lobe epilepsy in rats // Basic and clinical neuroscience. 2014. Issue 5 (2). P. 124-130.

9. Anticonvulsant activity of solasodine isolated fromSolanum sisymbriifoliumfruits in rodents / Chauhan K. et. al. // Pharmaceutical Biology. 2010. Vol. 49, Issue 2. P. 194-199. doi: 10.3109/13880209.2010.508499

10. Medicinal compounds with antiepileptic/anticonvulsant activities / Zhu H.-L. et. al. // Epilepsia. 2013. Vol. 55, Issue 1. P. 3-16. doi: 10.1111/epi.12463

11. Herbal Products and GABA Receptors / Johnston G. A. R. et. al. // Encyclopedia of Neuroscience. 2009. P. 1095-1101. doi: 10.1016/b978-008045046-9.00868-8

12. Protopine inhibits serotonin transporter and noradrenaline transporter and has the antidepressant-like effect in mice models / Xu L.-F. et. al. // Neuropharmacology. 2006. Vol. 50, Issue 8. P. 934-940. doi: 10.1016/j.neuropharm.2006.01.003

13. Wasowski C., Marder M. Flavonoids as GABA receptor ligands: the whole story? // Journal of experimental pharmacology. 2012. Issue 4. P. 9-24. doi: 10.2147/jep.s23105

14. Effects of atropine sulphate on seizure activity and brain damage produced by soman in guinea-pigs: ECoG correlates of neuropathology / Carpentier P. et. al. // Neurotoxicology. 2000. Issue 21 (4). P. 521-540.

15. Rosmarinic acid is anticonvulsant against seizures induced by pentylenetetrazol and pilocarpine in mice / Grigoletto J. et. al. // Epilepsy \& Behavior. 2016. Vol. 62. P. 27-34. doi: 10.1016/j.yebeh.2016.06.037

Дата надходження рукопису 22.02.2018

Yuliya Prokopenko, PhD, Associate Professor, Department of Quality, Standardization and Certification of Medicines, Institute of Pharmacy Professionals Qualification Improvement, National University of Pharmacy, Pushkinska str., 53, Kharkiv, Ukraine, 61002

E-mail: yuliya.prok@gmail.com

Victoriya Georgiyants, Doctor of Pharmaceutical Sciences, Professor, Head of Department. Department of Pharmaceutical Chemistry, National University of Pharmacy, Pushkinska str., 53, Kharkiv, Ukraine, 61002

E-mail: vgeor@ukr.net 